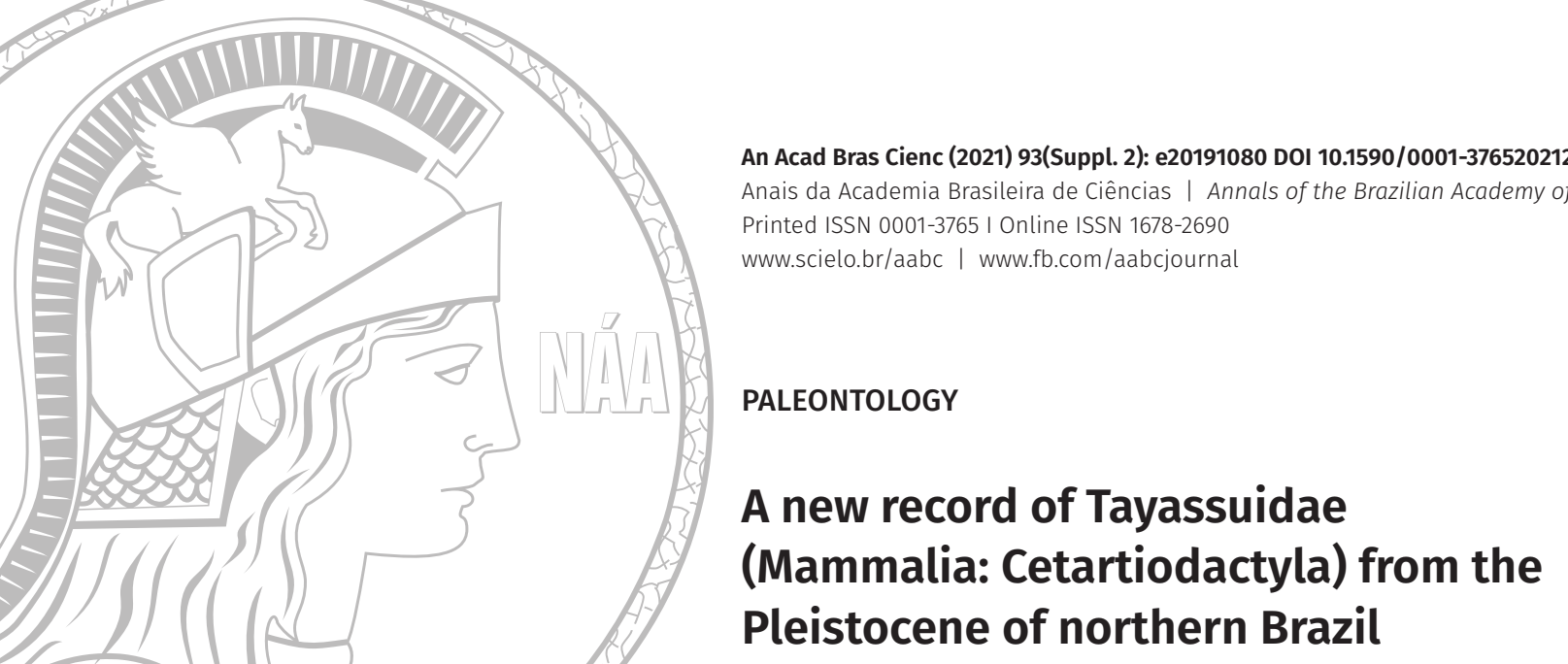

\title{
A new record of Tayassuidae (Mammalia: Cetartiodactyla) from the Pleistocene of northern Brazil
}

\author{
PAULA L. COPETTI, RODRIGO PARISI-DUTRA, ÁTILA A.S. DA-ROSA \& \\ LEONARDO KERBER
}

\begin{abstract}
In this contribution, we described a new fossil of a Pleistocene Tayassuidae from northern Brazil. The specimen is a left dentary with molars assigned to cf. Pecari tajacu recovered from an outcrop of the Rio Madeira Formation, State of Rondônia, Brazil. It represents the first Pleistocene fossil of this clade with stratigraphic provenance in the Amazon region of Brazil. This record contributes to the knowledge on the paleofauna of Rio Madeira Formation as well as extend the past geographic distribution of peccaries in South America.
\end{abstract}

Key words: Megafauna, paleobiogeography, Rio Madeira Formation, Rondônia.

\section{INTRODUCTION}

The South American Tayassuidae encompasses the extant Pecari tajacu (Linnaeus 1758), Tayassu pecari (Link 1795), Parachoerus wagneri (Rusconi 1930), and several extinct species recovered from Pliocene-Quaternary strata of this continent (e.g., Rusconi 1930, Gasparini \& Zurita 2005, Gasparini \& Ferrero 2010, Gasparini 2011, Gasparini et al. 2009, 2011, 2014, Avilla et al. 2013, Montellano-Ballesteros et al. 2014, Parisi Dutra et al. 2017a; but see Frailey \& Campbell 2012 and discussion in Parisi-Dutra et al. 2017a,b). According to Parisi-Dutra et al. (2017a), the Quaternary fossils include records of the three extant taxa, plus the extinct Platygonus Le Conte 1848, that surpassed the Pliocene/ Pleistocene boundary; Catagonus Ameghino 1904, with two extinct species: C. metropolitanus Ameghino, 1904 (Early Pleistocene, Argentina) and C. bonaerensis Ameghino, 1904 (Middle Pleistocene?-Late Pleistocene/Early Holocene,
Argentina and Uruguay); and Brasiliochoerus stenocephalus (Lund in Reinhardt 1880) (Middle Pleistocene-Late Pleistocene/Early Holocene, Brazil, Argentina, Bolivia, and Uruguay) (see Gasparini et al. 2009, 2013, 2014, 2019, Gasparini \& Ubilla 2011, Parisi-Dutra et al. 2017a). In this communication, we report a tayassuid fossil exhumed from Pleistocene beds of the Rio Madeira Formation, Rondônia, Brazil, which represents the first record of peccaries with stratigraphic provenance from the Amazon region of Brazil.

\section{MATERIALS AND METHODS}

\section{Geological and paleontological context}

The specimen UFSM 11606 was found in a project of paleontological rescue during the construction of the Jirau Hydroelectric Powerplant, Rondônia, Brazil, located around $120 \mathrm{~km}$ of Porto Velho (Fig. 1). The fossil was recovered from a conglomeratic deposit ("mucururu"; see Costa 


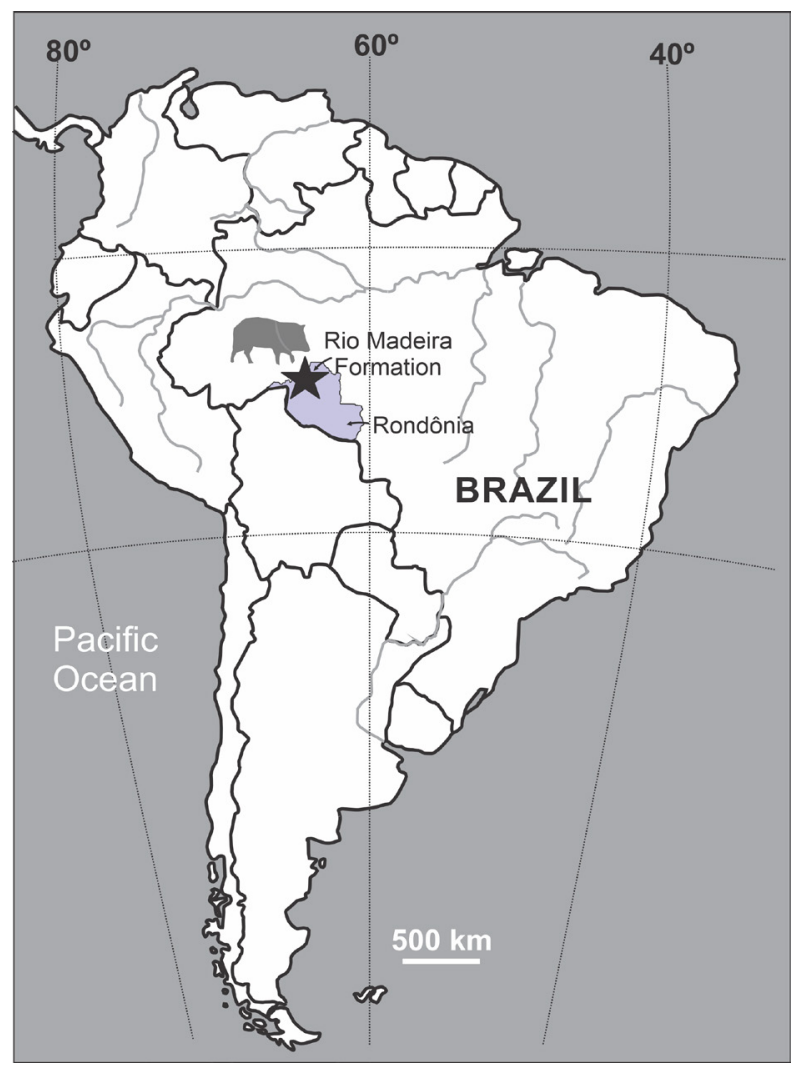

Figure 1. Geographic location of the Rio Madeira Formation (Pleistocene), State of Rondônia, Brazil.

1991) of the Rio Madeira Formation, located at

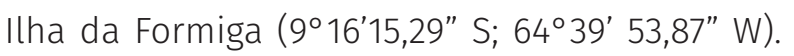
The fossiliferous levels of this formation were originated by a fluvial system (see Quadros et al. 2006) during the latest Middle Pleistocene/ Late Pleistocene (radiocarbon dating: $27 \mathrm{ka}$ BP and > 46 ka BP; Rizzotto et al. 2006; Accelerator Mass Spectrometry, Thermoluminescence, and Optically Stimulated Luminescence: 130,000 to 9,000 years BP; Da-Rosa et al. 2012)

The Pleistocene fossils from northwestern Brazil (see Simpson \& Paula-Couto 1981, PaulaCouto 1983, Ranzi 1999, 2000) are important to understand the origin of the modern Amazon biota. With the intense mining activity in the State of Rondônia, since the 1980s, several fossils have been discovered in the Rio Madeira Formation, including records of Eremotherium (Megatheriidae), Holmesina rondoniensis (Pampatheriidae), Glyptodon clavipes (Glyptodontidae), Toxodon aff. platensis (Toxodontidae), Tapirus rondoniensis (Tapiridae), Inia (Cetacea), Trichechus hesperamazonicus (Trichechidae), and Neochoerus aff. sulcidens (Caviidae) (Adamy \& Pereira 1991, Cozzuol 1999, Holanda et al. 2011, Cozzuol et al. 2005, 2006, Nascimento 2008, Góis et al. 2012, Perini et al. 2020).

\section{Institutional abbreviations}

UFSM, paleontological collection of the Laboratório de Estratigrafia e Paleobiologia of the Universidade Federal de Santa Maria, Santa Maria, Brazil.

\section{RESULTS AND DISCUSSION}

\section{Systematic paleontology}

Cetartiodactyla Montgelard, Catzeflis and Douzery 1997

Suiformes Jaeckel 1911

Suoidea Gray 1821

Tayassuidae Palmer 1897

cf. Pecari tajacu (Linnaeus 1758)

Referred material: UFSM 11606, left dentary with m1-m3. A 3D model of the specimen is available in Copetti et al. (2020a).

Geographic and stratigraphic provenance: Rio Madeira Formation (Pleistocene), Rondônia, Brazil.

Description: UFSM 11606 is a left dentary preserving the m1-m3 (Fig. 2). The specimen preserves the body of the dentary, but the symphysis and the vertical mandibular ramus are missing. There is a small portion of the coronoid process located posteriorly to the m3 (Fig. 2a-b). The ventral margin is slightly convex at the middle portion, becoming rectilinear at the level of the premolars. Anteriorly to the preserved portion of the angular process, there 
is a concavity on the ventral margin of the dentary (Fig. 2a).

The teeth are brachydont and bunodont, showing four main cusps: protoconid and metaconid mesially, separated by a valley from the hypoconid and entoconid distally, which have little wear (Fig. 2c). The $\mathrm{m} 1$ and $\mathrm{m} 2$ display rectangular outline in occlusal view (Fig. 2c). In occlusal view, a slight constriction at the middle portion of the teeth can be observed. The $\mathrm{m} 3$ is mesiodistally more elongated, with subrectangular outline due to the presence of a third lobe (Fig. 2c).

The $\mathrm{m} 1$ shows four worn main cusps (protoconid and metaconid mesially, separated by a valley from the hypoconid and entoconid distally). This tooth, which is the smallest of the series, shows mesial and distal cingula. Other conulids are not present due to the wear of the tooth (Fig. 2c).

The m2 shows more wear on the protoconid, metaconid, and entoconid than on the hypoconid (Fig. 2c). Like the m1, this tooth shows a cingulum labiolingually extended in the mesial and distal regions of the tooth. In the center of the tooth, distally to the protoconid and metaconid, there is an accessory cuspid at the middle portion of the cingulum. These structures are separated from the distal region of the tooth by a transverse valley. In the distal

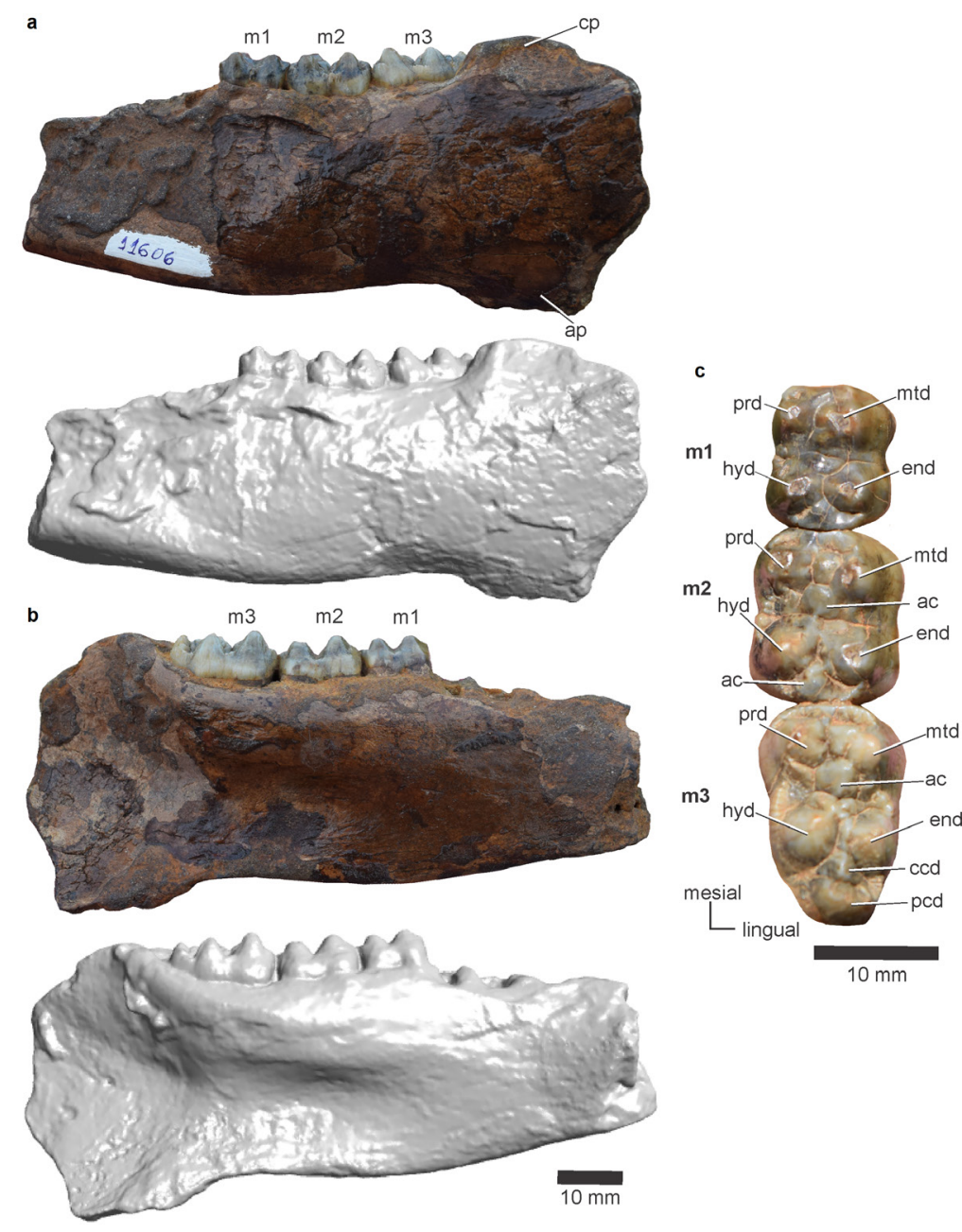

Figure 2. Left dentary with $\mathrm{m} 1-\mathrm{m} 3$ of cf. Pecari tajacu (UFSM 11606) from the Rio Madeira Formation, State of Rondônia, in lateral (a) and medial (b) views, respectively; detail of the occlusal surface (c). Dental nomenclature follows Gasparini et al. (2011). Abbreviations: ac, accessory cusp; ap, angular process; $\mathrm{cp}$, coronoid process; end, entoconid; hyd, hypoconid; mtd, metaconid; prd, protoconid; ccd, central conulid; pcd, posterior conulid. 
region, the hypoconid is located labially, the entoconid lingually, and an accessory cuspid distally to both conids at the middle line of the tooth (Fig. 2c).

The $\mathrm{m} 3$ is the least worn tooth of the series, and the cusps are sharper than in the $\mathrm{m} 1$ and m2 (Fig. 2c). Mesially, there is a marked cingulum, while labial and lingual cingula are not well developed. The protoconid and metaconid are well developed, and distally to them, there is an accessory cusp. The m3 shows an unworn third lobe, in which two main conulids can be observed, the central and distal ones (Fig. 2c).

Dimensions. m1: mesiodistal length $(\mathrm{mdl})$ $12.50 \mathrm{~mm}$; labiolingual width (llw) - $7.86 \mathrm{~mm}$; m2: mdl - 14.15mm, llw - 9.23 mm; m3: mdl - 18.37 $\mathrm{mm}$, Ilw- $9.41 \mathrm{~mm}$.

\section{Morphology and taxonomy of UFSM 11606}

The body of the dentary of UFSM 11606 is lower than B. stenocephalus and similar to T. pecari and P. tajacu. The ventral margin is slightly convex at its middle portion, differencing from B. stenocephalus, in which the ventral margin is almost rectilinear (Copetti et al. 2020b). The mandible and molars of T. pecari and P. tajacu are quite similar. However, some traits present in UFSM 11606 have been employed to differentiate them. According to Frailey \& Campbell (2012: Fig. 10), the mandible of T. pecari shows the middle ventral outline of the dentary slightly convex, becoming rectilinear at the ventral margin of the symphysis, while the dentary of P. tajacu is convex at the middle portion of the ventral margin, becoming rectilinear at the level of the premolars. In this sense, UFSM 11606 share the same pattern with P. tajacu.

The molars are brachydont and bunodont, not high-crowned as P. wagneri and B. stenocephalus. The lower molars have similar occlusal morphology, but according to Woodburne (1968) they have some differences in proportions concerning the mesiodistal length (mdl) and labiolingual width (llw) of the m1 (T. pecari - mdl: 14-16.25 mm, llw: 10.9-14.4 mm; P. tajacu - mdl: 10.3-13.3 mm, llw: 8.80-10.80 mm; UFSM 11606 - mdl: 12.50 mm, llw: 7.86 mm), mesiodistal length of the m2 (T. pecari: 15.1518.35 mm; P. tajacu: 12-14.95 mm; UFSM 11606: $14.15 \mathrm{~mm}$ ), and labiolingual width of the $\mathrm{m} 3$ ( $T$. pecari: 12.65-16.20 mm; P. tajacu: 9.45-12.40; UFSM 11606: $9.41 \mathrm{~mm}$ ). Following Woodburne (1968), UFSM 11606 falls in the size range predicted to $P$. tajacu. The distal region of the $\mathrm{m} 1$ and $\mathrm{m} 2$ of $T$. pecari, where the accessory cusp is located (see Gasparini et al. 2011), projects more distally than in UFSM 11606.

However, these mentioned traits present in UFSM 11606 are very subtle to assign the specimen confidently to P. tajacu, because they can be variable during the ontogeny (see Montellano-Ballesteros et al. 2014), and the most diagnostic features are present in the premolars (see Woodburne 1968, Gasparini \& Zurita 2005). Hence, we employed the use of cf. to identify the specimen from Rio Madeira Formation.

\section{Final remarks}

The specimen UFSM 11606 is assigned to cf. Pecari tajacu, the collared peccary. This fossil represents the first record of a Pleistocene tayassuid with stratigraphic provenance in the Amazon region of Brazil. Besides that, it contributes to the knowledge on the paleofauna of Rio Madeira Formation as well as extend the past geographic distribution of peccaries in South America. Although a fossil of T. pecari was mentioned for the State of Amazonas (Ranzi 1999), the data on collection and morphology are unavailable (Gasparini et al. 2014).

The available features present in UFSM 11606 resembles Pecari tajacu regarding size and mandible outline. This tayassuid has the largest geographic distribution among extant 
species, recorded from north-central Argentina to the southwestern USA. In South America, the collared peccary is recorded in deposits from the Middle Pleistocene to Holocene from Argentina (Buenos Aires Province), Brazil (States of Minas Gerais, Tocantins, Ceará, Paraná, and Rio Grande do Norte), Peru (Tumbes Department), and Venezuela (Falcón and Zulia States) (see Fonseca 1979, Dias-da-Silva et al. 2010, Gasparini 2011, Gasparini et al. 2014, Montallenos-Ballesteros et al. 2014).

\section{Acknowledgments}

We thank: Coordenação de Aperfeiçoamento de Pessoal de Nivel Superior - Brazil (CAPES) - Finance Code 001 to PLC; Conselho Nacional de Desenvolvimento Científico e Tecnológico (CNPq 422568/2018-0, 309414/2019-9 to LK, 313494/2018-5 to AASR); Germán Mariano Gasparini and Raúl Vezzosi for their useful comments. We also thank Energia Sustentável do Brasil, for supporting the recovery of the material and subsequent studies.

\section{REFERENCES}

ADAMY A \& PEREIRA LAC. 1991. Projeto Ouro e Gemas - Frente Rondônia. Relatório Anual. Companhia de Pesquisa de Recursos Minerais, p. 8-35.

AVILLA LS, MÜLLER L, GASPARINI GM, SOIBELZON L, ABSOLON B, PÊGO FB \& BAFFA O. 2013. The northernmost record of Catagonus stenocephalus (Lund in Reinhardt, 1880) (Mammalia, Cetartiodactyla) and its palaeoenvironmental and palaeobiogeographical significance. I S Am Earth Sci 42: 39-46.

COPETTI PL, GASPARINI GM, PEREIRA JC, FONTOURA E, LOPES RP \& KERBER L. 2020b. A skull of the extinct tayassuid Brasiliochoerus stenocephalus (Lund in Reinhardt, 1880) (Mammalia, Cetartiodactyla) from the Late Pleistocene of southern Brazil: morphology and taxonomy. Hist Biol. Online first.

COPETTI PL, PARISI-DUTRA R, DA-ROSA AAS \& KERBER L. 2020a. A new fossil of Tayassuidae (Mammalia: Artiodactyla) from the Pleistocene of northern Brazil. 3D model related to the publication: A new record of Tayassuidae (Mammalia: Cetartiodactyla) from the Pleistocene of northern Brazil. Morphomuseum, online first (10.18563/journal.m3.105).
COSTA ML. 1991. Os Mucururus de Rondônia: considerações mineralógicas e geoquímicas. III Simpósio de Geologia da Amazônia, Belém, Brazil: 464-478.

COzzUOL M. 1999. Mamíferos acuáticos y la antigüidad de los depositados cuaternários del Alto Río Madeira (Rondônia, Brasil). Mamíferos acuáticos y la antigüidad de los depositados cuaternários del Alto Río Madeira (Rondônia, Brasil). Congresso Internacional Evolución Neotropical del Cenozoico, La Paz, Bolivia.

COZZUOL MA, HOLANDA EC, NASCIMENTO ER \& WEISS FE. 2005. Registro do gênero Neochoerus (Rodentia, Caviomorpha, Hydrochoeridae) para o Pleistoceno superior da Amazônia sul-ocidental. Paleo 2005. Boletim da Sociedade Brasileira de Paleontologia: 43-44.

COZZUOL MA, SILVA SAF, NASCIMENTO ER \& HOLANDA EC. 2006. Registros de vertebrados para o Cenozóico superior da Amazônia ocidental: idade, paleoambiente e relações paleobiogeográficas. $V$ Simposio Brasileiro de Paleontologia de Vertebrados. Santa Maria, Brazil.

DA-ROSA AAS, LEAL LA, PIRES EF, MENESES M \& SAYÃO JM. 2012. Datação de depósitos sedimentares do Rio Madeira na região de abrangência do AHE Jirau, Rondônia, norte do Brasil. XLVI Congresso Brasileiro de Geologia, Santos, Brazil.

DIAS-DA-SILVA D, SEDOR FA \& OLIVEIRA EV. 2010. A presença de Catagonus e Tayassu (Artiodactyla, Tayassuidae) no Pleistoceno do Estado do Paraná, Brasil. $7^{\circ}$ Simpósio Brasileiro de Paleontologia de Vertebrados, Rio de Janeiro, Brazil.

FONSECA JS. 1979. Tayassuideos do Pleistoceno das cavernas calcáreas de Minas Gerais. Universidade Federal do Rio Grande do Sul.

FRAILEY CD \& CAMPBELL KE. 2012. Two new genera of peccaries (Mammalia, Artiodactyla, Tayassuidae) from upper Miocene deposits of the Amazon Basin. J Paleontol 86(5): 852-877.

GASPARINI GM. 2011. Records and Stratigraphical Ranges of South American Tayassuidae (Mammalia, Artiodactyla). J Mamm Evol 20(1): 57-68.

GASPARINI GM \& FERRERO BS. 2010. The Tayassuidae (Mammalia, Artiodactyla) from the Quaternary of Entre Rios Province. A palaeofaunal review in Argentina. Neues Jahrb Geol Paläontol 256(2): 151-160.

GASPARINI GM \& UBILLA M. 2011. Platygonus sp. (Mammalia: Tayassuidae) in Uruguay (Raigón? Formation; Plioceneearly Pleistocene), comments about its distribution and palaeoenvironmental significance in South America. J Nat Hist 45(45-46): 2855-2870. 
GASPARINI GM \& ZURITA AE. 2005. Primer registro fósil de Tayassu pecari (Link) (Mammalia, Artiodactyla) en la Argentina. Ameghiniana 42(2): 473-480.

GASPARINI GM, FERRERO BS, VEZZOSI RI \& BRUNETTO E. 2011. El registro de Tayassu pecari (Link, 1795) (Artiodactyla, Tayassuidae) en el Pleistoceno Tardío de la provincia de Santa Fe, Argentina. Aspectos biogeográficos y de distribución de una especie en retracción. Rev Mex Cienc Geol 28 203-211.

GASPARINI GM, KERBER L \& OLIVEIRA EV. 2009. Catagonus stenocephalus (Lund in Reinhardt, 1880) (Mammalia, Tayassuidae) in the Touro Passo Formation (Late Pleistocene), Rio Grande do Sul, Brazil. Taxonomic and palaeoenvironmental comments. Neues Jahrb Geol Paläontol 254(3): 261-273.

GASPARINI GM, PARISI-DUTRA R, LAMENZA GN, TONNI EP \& RUELLA A. 2019. Parachoerus carlesi (Mammalia, Tayassuidae) in the Late Pleistocene (northern Argentina, South America): paleoecological and palaeobiogeographic considerations. Hist Biol 31: 1082-1088.

GASPARINI GM, RODRIGUEZ SG, SOIBELZON LH, BEILINSO NE, SOIBELZON E \& MISSAGIA RV. 2014. Tayassu pecari (Link, 1795) (Mammalia, Cetartiodactyla): comments on its South American fossil record, taxonomy and paleobiogeography. Hist Biol 26(6): 785-800.

GÓIS F, SCILLATO-YANÉ GJ, CARLINI AA \& UBILLA M. 2012. Una nueva especie de Holmesina simpson (Xenarthra, Cingulata, Pampatheriidae) del pleistoceno de Rondônia, sudoeste de la Amazonia, Brasil. Rev Bras Paleontolog 15(2): 211-227.

HOLANDA EC, FERIGOLO J \& RIBEIRO AM. 2011. New Tapirus species (Mammalia: Perissodactyla: Tapiridae) from the upper Pleistocene of Amazonia, Brazil. J Mammal 92(1): 111-120.

MONTELLANO-BALLESTEROS M, RINCÓN AD \& SOLÓRZANO A. 2014. Record of tayassuids in? Late Pliocene to Quaternary deposits in Venezuela. Rev Bras Paleontolog 17(2): 169-182.

NASCIMENTO ER. 2008. Os Xenarthras Pilosa (Megatheriidae), Notoungulata (Toxodontidae) e Proboscidea (Gomphotheriidae) da Formação Rio Madeira, Pleistoceno Superior, estado de Rondônia, Brasil. Dissertação (Mestrado). Rio Grande do Sul: Universidade Federal do Rio Grande do Sul. (Unpublished)

PARISI-DUTRA R, CASALI DDM, MISSAGIA RV, GASPARINI GM, PERINI FA \& COZZUOL MA. 2017a. Phylogenetic Systematics of Peccaries (Tayassuidae: Artiodactyla) and a
Classification of South American Tayassuids. J Mammal Evol 24: 345-358.

PARISI-DUTRA R, PERINI FA, COZZUOL MA, MISSAGIA RV \& GASPARINI GM. 2017b. On the supposed presence of Miocene Tayassuidae and Dromomerycinae (Mammalia, Artiodactyla) in South America. XXX Jornadas Argentinas de Mastozoología (SAREM). Bahía Blanca.

PAULA-COUTO CD. 1983. Fossil mammals from the Cenozoic of Acre, Brazil, VI-Edentata Cingulata. Iheringia, Série Geologia 8: 33-49.

PERINI F, NASCIMENTO ER \& COZZUOL MA. 2020. A new species of Trichechus Linnaeus, 1758 (Sirenia, Trichechidae), from the upper Pleistocene of southwestern Amazonia, and the evolution of Amazonian manatees. J Vertebr Paleontol 39(5): e1697882.

QUADROS MLES, RIZZOTTO GJ, OLIVEIRA JGF \& CASTRO M. 2006. Depósitos fluviais da Formação Rio Madeira, Pleistoceno Superior da Bacia do Abunã, Rondônia. IX Simpósio de Geologia da Amazônia, Belém, Brazil.

RANZI A. 1999. Fossil mammals of the Amazon as a portrait of a Pleistocene environment. Mammals of the Neotropics. The Central Neotropics, Ecuador, Peru, Bolivia, Brazil, 3: 20-26.

RANZI A. 2000. Paleoecologia da Amazônia: megafauna do Pleistoceno. Editora da UFSC.

RIZZOTTO GJ, CRUZ NM, OLIVEIRA JG, QUADROS MLES \& CASTRO JM. 2006. Paleoambiente e o registro fossilífero pleistocênico dos sedimentos da Formação Rio Madeira. IX Simpósio de Geologia da Amazônia.

RUSCONI C. 1930. Las especies fósiles argentinas de pecariesy sus relaciones con las del Brasil y Norteamérica. Ann Mus Nac Hist Nat Bernardino Rivadavia 36: 121-241.

SIMPSON GG \& PAULA-COUTO C. 1981. 'Fossil mammals from the Cenozoic of Acre, Brazil III-Pleistocene Edentata Pilosa, Proboscidea, Sirenia, Perissodactyla and Artiodactyla. Iheringia, Série Geologia 6: 11-73.

WOODBURNE MO. 1968. The cranial myology and osteology of Dicotyles tajacu, the collared peccary, and its bearing on classification. Memoirs of the Southern California Academy of Sciences 7: 1-48. 


\section{How to cite}

COPETTI PL, PARISI-DUTRA R, DA-ROSA AAS \& KERBER L. 2021. A new record of Tayassuidae (Mammalia: Cetartiodactyla) from the Pleistocene of northern Brazil. An Acad Bras Cienc 93: e20191080. DOI 10.1590/00013765202120191080 .

Manuscript received on September 17, 2019;

accepted for publication on December 9, 2019

PAULA L. COPETTI 1

https://orcid.org/0000-0003-2596-9945

\section{RODRIGO PARISI-DUTRA ${ }^{2}$}

https://orcid.org/0000-0003-2021-900

\section{ÁTILA A.S. DA-ROSA ${ }^{1,3}$}

https://orcid.org/0000-0003-4074-0794

\section{LEONARDO KERBER ${ }^{1,4,5}$}

https://orcid.org/0000-0001-8139-1493

${ }^{1}$ Universidade Federal de Santa Maria, Programa de Pós-Graduação em Biodiversidade Animal, Av. Roraima, 1000, 97105-900 Santa Maria, RS, Brazil

${ }^{2}$ Universidade Federal de Minas Gerais, Instituto de Ciências Biológicas, Departamento de Zoologia, Programa de Pós-Graduação em Zoologia, Avenida Antônio Carlos, 6627, 31270-901 Belo Horizonte, MG, Brazil

${ }^{3}$ Universidade Federal de Santa Maria, Departamento de Geociências, Av. Roraima, 1000, 97105-900 Santa Maria, RS, Brazil ${ }^{4}$ Universidade Federal de Santa Maria, Centro de Apoio à Pesquisa Paleontológica, Rua Maximiliano Vizzotto, 598, 97230-000 São João do Polêsine, RS, Brazil

${ }^{5}$ Museu Paraense Emílio Goeldi, Coordenação de Ciências da Terra e Ecologia, Av. Perimetral, 1901, 66077-830 Belém, PA, Brazil

Correspondence to: Paula Lopes Copetti

E-mail:copettipaulalopes@gmail.com

\section{Author contributions}

PLC, RPD, AASR, and LK conducted the research. The 3D model was generated by L.K. The manuscript was written by PLC. All authors approved the submission of this work.

\section{(cc) BY}

